\title{
The legendary hump-backed mahseer Tor sp. of India's River Cauvery: an endemic fish swimming towards extinction?
}

\author{
Adrian C. Pinder ${ }^{1,2, *}$, Rajeev Raghavan ${ }^{1,3,4}$, J. Robert Britton ${ }^{2}$ \\ ${ }^{1}$ Mahseer Trust, c/o The Freshwater Biological Association, East Stoke River Laboratory, Wareham, Dorset BH20 6BB, UK \\ ${ }^{2}$ Faculty of Science and Technology, Bournemouth University, Fern Barrow, Poole, Dorset BH12 5BB, UK \\ ${ }^{3}$ Conservation Research Group (CRG), St Albert's College, Kochi, Kerala, 682 018, Kerala, India \\ ${ }^{4}$ Laboratory of Systematics, Ecology and Conservation, Zoo Outreach Organization (ZOO), Coimbatore, 641 035, Tamil Nadu, India
}

\begin{abstract}
The Western Ghats region of India is an area of exceptional freshwater biodiversity and endemism. Mahseer of the genus Tor are considered prized sport fishes of great cultural significance; nevertheless, they are threatened as a result of increasing anthropogenic stressors. In the River Cauvery, the mahseer community comprises a 'blue-finned' and an orange-finned, 'hump-backed' fish. Whilst it is not yet known whether these are distinct species or 2 different phenotypes, evidence suggests that the hump-backed phenotype is endemic to the river, whereas the blue-finned phenotype was introduced in the 1980s. Angler-catch data from a managed fishery on the River Cauvery, gathered between 1998 and 2012 and comprising $23620 \mathrm{~h}$ of fishing effort, revealed that captured individuals ranged in size from 0.45 to $46.8 \mathrm{~kg}$, with the blue-finned phenotype comprising $95 \%$ of all captured fish and the remainder being hump-backed. The catch per unit effort (CPUE) of the blue-finned phenotype significantly increased over the study period, while the mean weight of individual fish significantly declined. By contrast, the CPUE of the hump-backed phenotype declined significantly over the period, with individual mean weights significantly increasing. These data suggest a recent recruitment collapse in the hump-backed phenotype resulting in an ageing population that may be headed towards extinction. The introduced blue-finned phenotype, however, continues to recruit strongly, suggesting that the mahseer community of the River Cauvery has undergone considerable shifts in the last $30 \mathrm{yr}$.
\end{abstract}

KEY WORDS: Western Ghats · Tor khudree - Tor mussullah · Catch and release - Endemic . Recruitment $\cdot$ Recreational fisheries

\section{INTRODUCTION}

Freshwater ecosystems and their biodiversity remain among the most endangered and poorly protected resources on Earth (Millennium Ecosystem Assessment 2005, Dudgeon 2011, Cooke et al. 2012), with almost 1 in 3 freshwater species facing a high risk of extinction (Collen et al. 2014). Of the 5785 species of freshwater fish assessed for their conservation

\footnotetext{
${ }^{*}$ Corresponding author: apinder@bournemouth.ac.uk
}

status by the IUCN, more than $36 \%$ are threatened, and over 60 species have gone extinct since 1500 (Carrizo et al. 2013).

The Western Ghats region of India, part of the Western Ghats-Sri Lanka Biodiversity Hotspot, is an area of exceptional freshwater biodiversity and endemism (Dahanukar et al. 2011, Raghavan et al. 2015). Nevertheless, approximately half of the region's endemic fish species are threatened with

() The authors 2015. Open Access under Creative Commons by Attribution Licence. Use, distribution and reproduction are unrestricted. Authors and original publication must be credited. 
extinction (Dahanukar et al. 2011), a result of escalating anthropogenic pressures and threats, lack of governmental support for freshwater fish conservation, jurisdictional issues and oversights, poor enforcement of existing laws and implementation of top-down approaches (Dahanukar et al. 2011, Raghavan et al. 2011, 2013, Pinder \& Raghavan 2013). In the region, no freshwater fish has received as much attention from the public as the mahseer (Tor spp.), a group of large-bodied fishes of the Cyprinidae family. These species are represented in the ancient Indian literature (Nautiyal 2014), are revered as gods (Dandekar 2011) and have been globally recognised as premier game fishes since colonial times (Thomas 1873, Dhu 1923, MacDonald 1948). They are, however, among the most threatened groups of freshwater fish in the Western Ghats, impacted by habitat loss and destructive fishing, yet there are many gaps in our knowledge of their taxonomy, natural histories and population statuses (Pinder \& Raghavan 2013). Of particular concern are their systematics and taxonomy, with continuing ambiguity about the identity and distribution of species. The increasing volume of information in the peer-reviewed literature has also been relatively unhelpful to date as it often provides contrasting perspectives on these subjects (cf. Knight et al. 2013, Khare et al. 2014).

In British colonial times, the mahseer of the River Cauvery in the Western Ghats were premier sport fishes, but interest in their fishery diminished following Indian independence in 1947, leading many to assume the fish had become extinct. In 1978, however, a small team of British explorers were successful in catching mahseer weighing up to $42 \mathrm{~kg}$ (TWFT 1984), reigniting global interest in the river as a premier freshwater sport fishing destination and launching a new era of Indian angling ecotourism (Everard \& Kataria 2011). The fishery was developed on strict catch-and-release $(\mathrm{C} \& \mathrm{R})$ principles that realised tangible river conservation and societal benefits (Pinder \& Raghavan 2013). Despite these benefits, governmental reinterpretation of the Indian Wildlife Protection Act of 1972 resulted in a shutdown of the angling camps from 2012, exposing aquatic biodiversity generally and mahseer specifically to elevated levels of illegal and destructive levels of exploitation (e.g. dynamite fishing) in the river.

A recent study on the mahseer fishery of the River Cauvery highlighted the value of angler catch returns in monitoring temporal population trends in mahseer numbers and weight (Pinder et al. in press), and highlighted a marked shift in the weight of indi- vidual fish being captured despite a relatively consistent methodology used across the time series, with increasingly smaller fish being captured over time. Although the study speculated that this related to a change in the mahseer community structure from the endemic hump-backed (orange-finned) phenotype (that grows to over $50 \mathrm{~kg}$ ) to a distinct blue-finned, smaller phenotype, this was not tested. In the present study we thus further examined the dataset of Pinder et al. (in press), with the following objectives: (1) to quantify any shift in mahseer community structure and the current status of both phenotypes; (2) to identify the vulnerability to extinction of the humpbacked phenotype in the River Cauvery and the conservation implications of the presence of the bluefinned phenotype; and (3) to present the urgency associated with defining the true scientific identity of the 'hump-backed mahseer' to advance the ecological knowledge required to inform species-specific conservation action. Note that whilst the 2 mahseer phenotypes have previously been referenced respectively as T. mussullah and T. khudree, their taxonomic classifications are currently under scrutiny, and to avoid perpetuating erroneous scientific names, they are referred to here as only phenotypes, i.e. as 'hump-backed' and 'blue-finned', respectively. Note that the hump-backed phenotype has, historically, only been recorded from the River Cauvery basin (Thomas 1873), including its tributaries, the Kabini (TWFT 1984), Bhavani (Hora 1943) and the Moyar (Jayaram 1997); and thus, based on its restricted distribution alone, it may be considered as highly vulnerable to extinction (Helfman 2007, Giam et al. 2011). By contrast, the blue-finned phenotype was not recorded in the river prior to 1993 and is believed to have originated from artificially propagated stock (Desai 2003).

\section{MATERIALS AND METHODS}

The study area on the River Cauvery was the Galibore Fishing Camp, 1 of 4 former angling camps situated on the River Cauvery encompassed by the Cauvery Wildlife Sanctuary (an IUCN Category IV Protected Area) in the state of Karnataka, part of the Western Ghats in Southern India (Fig. 1). Between mid-January and mid-March of 1998 to 2012, the Galibore fishery was subject to regulated angling pressure (maximum 10 rods $\mathrm{d}^{-1}$ ), practising a very strict C\&R policy. Structured catch data collected during this period included daily records of individual angler identity (name); hours fished 


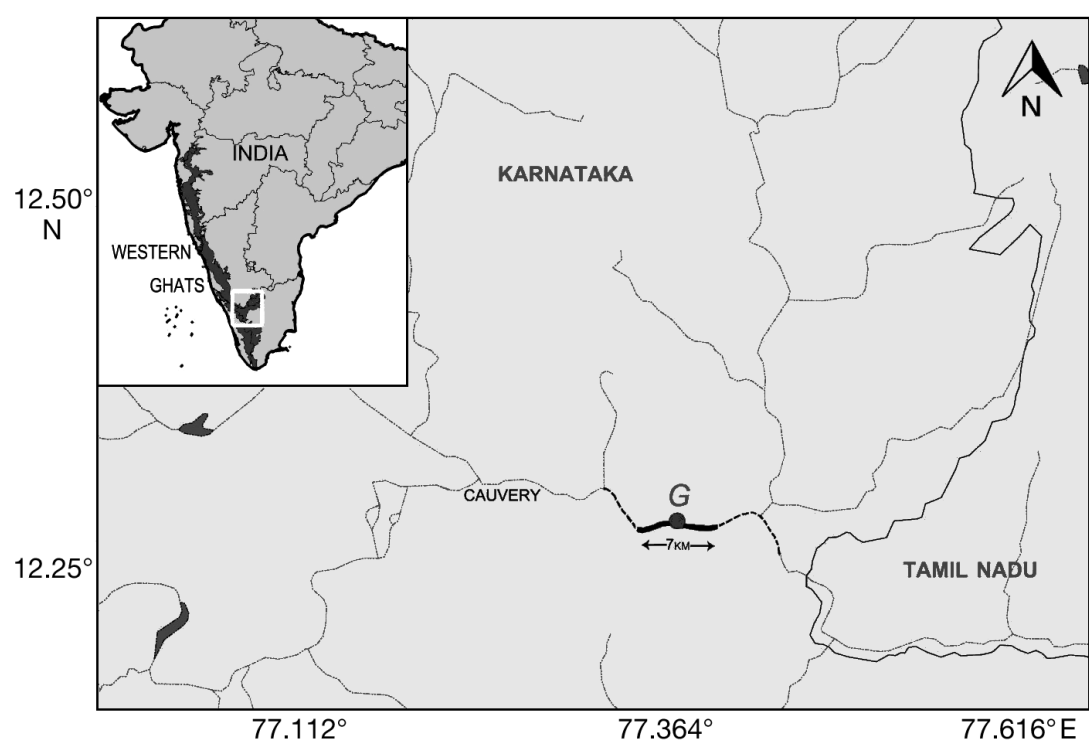

Fig. 1. Location of the River Cauvery and the study area in the Western Ghats of India. The solid line represents the $7 \mathrm{~km}$ Galibore fishery (G). The dashed line represents the $22 \mathrm{~km}$ extent of the former catch and release mahseer fishery; light grey lines show the course of the River Canvery and its tributaries

(effort); number of fish caught; weight of individual fish (the standard metric used by anglers was imperial pounds [lbs], where $1 \mathrm{lb}=0.45 \mathrm{~kg})$; and notes relating to mahseer phenotype (denoted as humpbacked, $\mathrm{H}_{\text {; }}$ and blue-finned, B). With the exception of 2 years (1999 and 2000), a sub-sample of catch returns spanning 1998 to 2012 were available from the fishery manager and complemented by additional returns retained by anglers over the same period. A summary of the data for each year is presented in Table 1.

Table 1. Temporal resolution of data recovered to determine catch per unit effort (CPUE) for mahseer. Individual angler numbers $\mathrm{yr}^{-1}$ (1998-2012) and hours fished (effort) between January and March in each year are given

\begin{tabular}{|ccrrr|}
\hline \multirow{2}{*}{ Year } & $\begin{array}{c}\text { Total no. } \\
\text { of anglers }\end{array}$ & $\begin{array}{c}\text { Total hours } \\
\text { fished }\end{array}$ & $\begin{array}{c}\text { No. of mahseer captured: } \\
\text { Hump-backed }\end{array}$ & Blue-finned \\
\hline 1998 & 6 & 580 & 14 & 59 \\
2001 & 9 & 820 & 38 & 153 \\
2002 & 10 & 1080 & 6 & 81 \\
2003 & 19 & 1920 & 80 & 148 \\
2004 & 25 & 2640 & 95 & 342 \\
2005 & 28 & 2604 & 25 & 407 \\
2006 & 17 & 1608 & 6 & 228 \\
2007 & 27 & 2632 & 3 & 452 \\
2008 & 33 & 3188 & 5 & 1022 \\
2009 & 11 & 1196 & 4 & 346 \\
2010 & 29 & 1984 & 9 & 887 \\
2011 & 35 & 2388 & 1 & 1095 \\
2012 & 10 & 980 & 3 & 653 \\
\hline
\end{tabular}

While all larger mahseer $(>10$ lbs [ $>4.5 \mathrm{~kg}]$ ) were typically weighed to the nearest pound using spring-loaded weighing scales, many weights for smaller individual fish were found to be restricted to estimates. Furthermore, where an angler recorded a large number of fish during a single $(4 \mathrm{~h})$ fishing session, records were typically limited to the weight of the largest fish, with the remaining catch enumerated, e.g. ' 6 fish to 18 lbs'. Following consultation with the camp manager and a selection of the anglers, and as per Pinder et al. (in press), these data were standardised by recording 1 fish at $18 \mathrm{lbs}$ with all other individuals recorded as weighing $5 \mathrm{lbs}$ (with $5 \mathrm{lbs}[2.25 \mathrm{~kg}]$ representing the threshold at which most anglers were considered to neither weigh nor estimate the weight of their fish). Where the weight of the largest individual did not exceed 5 lbs (either estimated or weighed), e.g. '9 fish to 5 lbs', data were standardised by applying a $50 \%$ weight reduction to the remaining 8 fish for which weights were not recorded. In this example, the adjusted record would account for 1 fish of $5 \mathrm{lbs}$ and 8 fish of $2.5 \mathrm{lbs}$. While we acknowledge the inherent limitations of these standardised data, the allocation of arbitrary weights (as guided by the local angling community) has facilitated a valuable measure of the numbers of young fish recruiting to the population over the course of the study period.

Catch returns were initially sorted into the respective phenotypes and enumerated as annual totals. To identify whether the number of blue-finned mahseer captured each year was a good predictor of the number of hump-backed mahseer captured, their relationship was tested using linear regression. To assess whether the differences in the number of each phenotype captured per year were significantly different, the gradient of the regression line $(b)$ was used to test the null hypothesis that equal numbers of the phenotypes were captured each year, with this accepted when $b$ was not significantly different from 1.0 and vice versa, based on its $95 \%$ confidence limits. The catch per unit effort (CPUE) of each phenotype was then determined for each year and expressed as the number of each phenotype captured per hour per year. Differences in CPUE value between the 2 phenotypes were tested using ANOVA. The temporal pattern in the CPUE of each 
phenotype was tested for significance using linear regression, where the independent variable was the number of years since the study commenced and the dependent variable was the annual CPUE of the mahseer phenotype. To identify whether there was a relationship between the temporal patterns in the CPUE of the hump-backed mahseer and the CPUE of the blue-finned mahseer, Pearson's correlation coefficient was used in cross-correlation, using time 0 (i.e. testing of CPUE data from the same year) and at time lags of -1 to $-3 \mathrm{yr}$.

For the weight of individual fish, differences between phenotypes were tested using a Mann-Whitney $U$-test because the data were not normally distributed. The temporal pattern in the mean weights of each phenotype was then tested for significance using linear regression, where the independent variable was the number of years since the study commenced and the dependent variable was the mean annual weight of the mahseer phenotype. This was also repeated for all fish captured, i.e. by combining data from both phenotypes.

Throughout the study, where error is expressed around the mean, it denotes standard error.

\section{RESULTS}

Over the study period, $23620 \mathrm{~h}$ of fishing effort were applied to C\&R of 6162 mahseer, ranging in size from 1 to $104 \mathrm{lbs}(0.45-46.8 \mathrm{~kg})$ in weight. Of these mahseer, $95 \%$ comprised the blue-finned phenotype, with the remainder being hump-backed (Table 1). The number of blue-finned and hump-backed mahseer captured per year were not significantly related $\left(\mathrm{R}^{2}=0.14, F_{1,11}=1.73, \mathrm{p}>0.05\right.$; Fig. $\left.2 \mathrm{a}\right)$ and the slope of this regression line $(b)$ indicated that significantly more blue-finned mahseer were captured per year than hump-backed mahseer (95\% confidence intervals: -0.09 to 0.02 ; Fig. 2a). The annual CPUE of the blue-finned phenotype was also significantly higher than that of the hump-backed phenotype (ANOVA: $\left.F_{1,22}=21.78, \mathrm{p}<0.01\right)$, with the mean CPUE of the blue-finned phenotype being $0.248 \pm 0.050$ ind. $\mathrm{h}^{-1}$ and that of the hump-backed phenotype being 0.014 \pm 0.005 ind. $h^{-1}$ (Fig. 2b,c). Across the study period, the CPUE of the blue-finned phenotype significantly increased with time (Fig. $2 b)\left(\mathrm{R}^{2}=0.70, F_{1,11}=25.65\right.$, $\mathrm{p}<0.01$ ), whereas it significantly decreased in the hump-backed phenotype $\left(\mathrm{R}^{2}=0.68, F_{1,11}=9.54, \mathrm{p}<\right.$ 0.01; Fig. 2c). The cross-correlation revealed that the relationship of the annual CPUE of the hump-backed phenotype was not significantly correlated to the

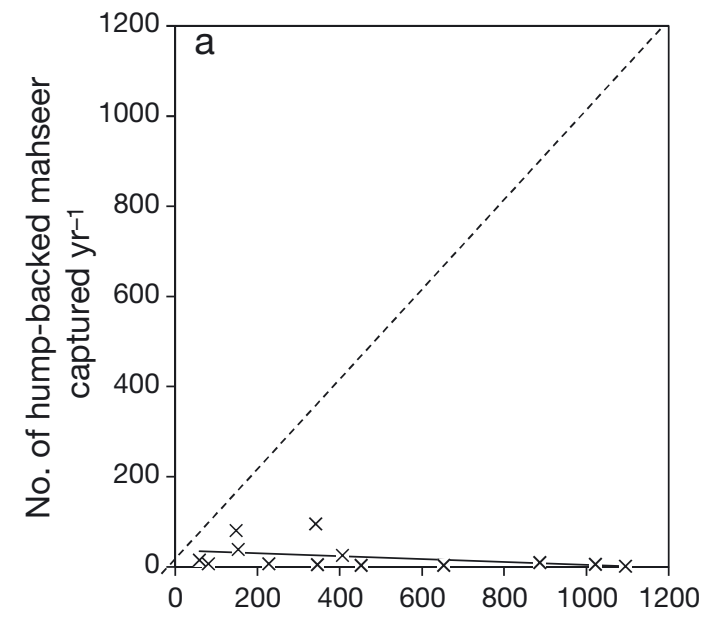

No. of blue-finned mahseer captured $\mathrm{yr}^{-1}$
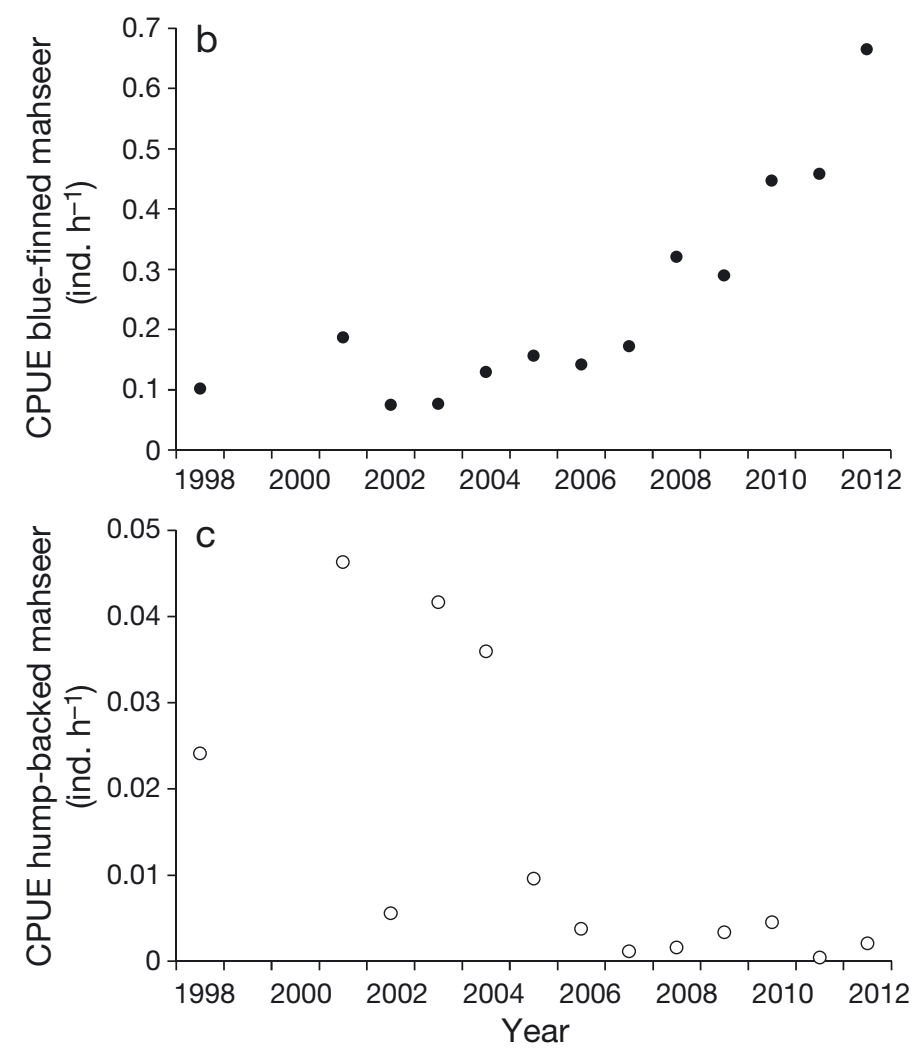

Fig. 2. (a) Comparison of the number of each mahseer phenotype captured per year $(x)$, where the solid line represents the fitted relationship (linear regression) and the dashed line represents the null hypothesis that equal numbers of each phenotype were captured each year. Annual catch per unit effort (CPUE) of (b) the blue-finned and (c) hump-backed mahseer across the study period. Error bars are not displayed for reasons of clarity

CPUE of the blue-finned mahseer at time $0,-2$ and $-3 \mathrm{yr}(\mathrm{r}=-0.49,-0.30$ and -0.25 , respectively, $\mathrm{p}>$ 0.05 in all cases), but was significant at time $-1 \mathrm{yr}$ $(-0.58, \mathrm{p}<0.05$; Fig. 2b,c). 
Across the study period, the mean weight of the hump-backed mahseer was $24.3 \pm 1.5 \mathrm{lbs}$ (range: 1-104 lbs [0.45-46.8 kg]) and that of the blue-finned was $7.8 \pm 0.1 \mathrm{lbs}$ (range: $1-62 \mathrm{lbs}[0.45-27.9 \mathrm{~kg}]$ ); this difference was significant (Mann-Whitney $U$-test: $Z=$ $-14.37, \mathrm{p}<0.01$; Fig. 3). For the hump-backed phenotype, mean weights per year significantly increased over the study period $\left(\mathrm{R}^{2}=0.45, F_{1,11}=8.82, \mathrm{p}<0.02\right)$, ranging between $16 \mathrm{lbs}(7.2 \mathrm{~kg})$ in 2001 and $67.5 \mathrm{lbs}$ $(30.4 \mathrm{~kg})$ in 2011 (Fig. 3a). In contrast, the mean weight of the blue-finned phenotype significantly decreased over the study period $\left(\mathrm{R}^{2}=0.63, F_{1,11}=\right.$ $18.60, \mathrm{p}<0.01)$, ranging between $13.8 \mathrm{lbs}(6.2 \mathrm{~kg})$ in 1998 and $5.4 \mathrm{lbs}(2.4 \mathrm{~kg})$ in 2012 (Fig. 3b). Indeed, across the study period, $42 \%$ of the captured bluefinned phenotype were below $5 \mathrm{lbs}(<2.25 \mathrm{~kg})$ in weight. When the data for both phenotypes were combined, the highest mean weight of captured fish was recorded in $1998(17.7 \pm 2.0 \mathrm{lbs} ; 8.0 \pm 0.9 \mathrm{~kg})$ and the lowest was in $2012(5.6 \pm 0.3 \mathrm{lbs} ; 2.5 \pm 0.1 \mathrm{~kg})$, with a significant temporal decline in mean weight also evident $\left(\mathrm{R}^{2}=0.83, F_{1,11}=51.71, \mathrm{p}<0.01\right)$.

\section{DISCUSSION}

The angler catch data revealed some distinct patterns in the composition of the mahseer catches over time, with a significantly increasing catch rate of the blue-finned phenotype and a significant decline in catch rates of the hump-backed phenotype. Despite considerable technological advances in recreational fishing gears (e.g. development of braided lines), the challenging environmental conditions and presence of sharp submerged rocks in the River Cauvery has dictated that angling techniques remained consistent over the period and provided a representative catch rate of all mahseer between 1 and 104 lbs (0.45$46.8 \mathrm{~kg}$ ) (Pinder et al. in press). Hence, these outputs indicate that the mahseer community of the river is primarily currently comprised of the blue-finned phenotype whose mean weight is substantially lower than that of the hump-backed phenotype. The combination of the significant decline in catch rate of the hump-backed phenotype and the significant increase in the sizes of individual fish captured suggests that there has been a relatively recent issue with their recruitment in the river, whereas this is not evident in the blue-finned phenotype.

The recruitment collapse of the hump-backed phenotype does not appear to be associated with antagonistic interactions between the 2 phenotypes, given the output of the cross-correlation. It does correspond

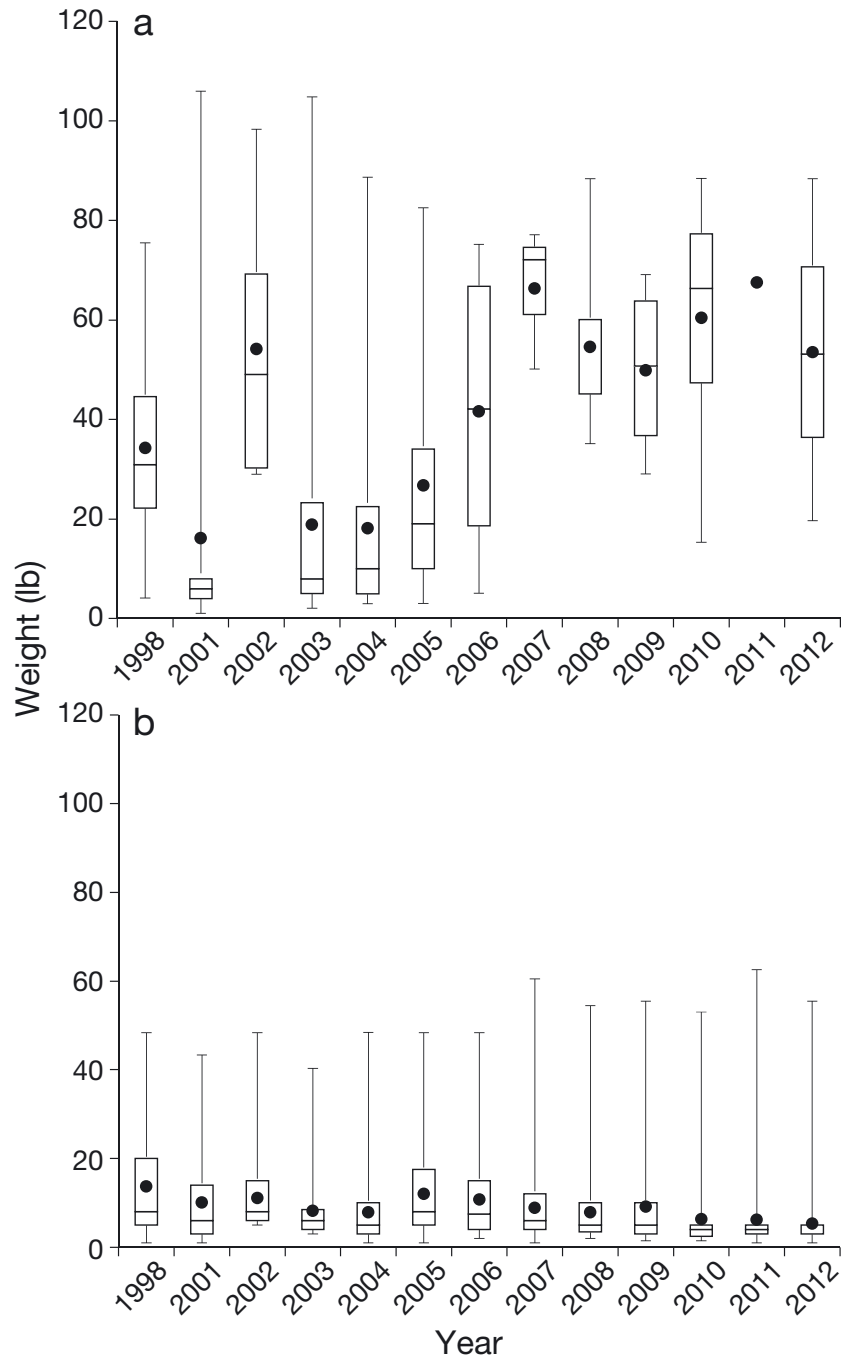

Fig. 3. Weight of individual mahseer captured per year for (a) hump-backed and (b) blue-finned. Filled circles represent mean annual weight, horizontal lines represent the 25th, 50th and 75th percentiles, and the error bars represent the 10 th and 90th percentiles. $1 \mathrm{lb}=0.45 \mathrm{~kg}$

with anecdotal reports of the failure of the 2004 monsoon (i.e. very low rainfall), which dramatically reduced river discharge during the 2005 fishing season and resulted in the observed mortality of several large hump-backed mahseer (M. Brown pers. comm.). Their overall decline was also coincident with an increase in angling pressure, and although C\&R was practised, it could be speculated that the capture and subsequent handling of some of the large hump-backed individuals resulted in their post-release mortality and thus loss from the spawning stock; however, there is no supporting anecdotal evidence of this. Irrespective of this, without action to remediate or mitigate this population decline and recruitment collapse in the hump-backed phenotype, their popula- 
tion in the River Cauvery appears to be increasingly unsustainable and heading towards extinction.

Historical information, including photographs, is critical to understand the status of species and populations (see McClenachan 2009, McClenachan et al. 2012) and reveals that only the hump-backed phenotype was captured and photographed during colonial times. Indeed, photographs of the hump-backed phenotype, as typified by its golden body and orange fins, are distributed throughout the angling literature and all depict individuals captured in the Cauvery river system, suggesting the absence of this phenotype in other rivers (Thomas 1873, Dhu 1923, MacDonald 1948, Shanmukha 1996). Moreover, until 1993, it was the only mahseer phenotype captured by anglers in the Cauvery, suggesting in all probability that this phenotype is endemic. The appearance of the blue-finned phenotype is likely to relate to fish movements and hatchery-reared fish that were initiated in the 1970s. In response to the realisation that a combination of anthropogenic threats was causing a rapid decline in mahseer stocks across India, the Tata Electric Companies (TEC) fish-seed hatchery at Lonavla, Maharashtra, began the large-scale breeding and culture of mahseer species (Tor khudree, T. tor, T. putitora and the ambiguous ' $T$. mussullah') for national distribution of fingerlings to augment stocks (Shanmukha 1996, Sehgal 1999, Ogale 2002, Desai 2003). The dates and geographical details of where brood-stock was acquired and the seed distribution of the exact species are scarce, although activities included the experimental hybridisation between mahseer species (Ogale \& Kulkarni 1987), and the translocation of species beyond their endemic geographical ranges (including outside the country) has been documented (Ogale 2002, Desai 2003). In 1978, the Trans World Fishing Team (TWFT) visited the TEC hatchery and provided the first record of bluefinned mahseer, describing the culture of 'a strikingly blue-finned fish', which was targeted for release in the nearby rivers and reservoirs (TWFT 1984). Sehgal (1999) and Desai (2003) have since reported the release of 150000 advanced fry/fingerlings of $T$. khudree to the River Cauvery by the Department of Fisheries of the State of Karnataka, with further documentation that stocking activity on the Cauvery included 30000 mahseer by the Fish Farmers Development Agency, Mysore (Shanmukha 1996), 15000 mahseer fingerlings to the Coorg Wildlife Society and 10000 to the Wildlife Association of South India (Ogale 2002).

The dataset used in the present study reveals that the blue-finned phenotype was sufficiently well established in the River Cauvery by 1998 to enable it to already be captured in greater numbers than the hump-backed phenotype, with individual specimens attaining weights up to $48 \mathrm{lbs}(21.6 \mathrm{~kg})$. Also, whereas the catch data suggest declines in the hump-backed phenotype associated with poor recruitment due to the declining catch rate and increasing individual fish size, data from the bluefinned phenotype suggest that sufficient recruitment occurred to enable large numbers of smaller fish to be captured by anglers, as $42 \%$ of all blue-finned mahseer captured in the study period were below $5 \mathrm{lbs}(<2.25 \mathrm{~kg})$ in weight. Due to the lack of detailed catch data prior to 1998, records on the blue-finned phenotype are limited to articles in the popular press and media. The earliest record communicating their presence was in 1993 during the mahseer world angling championships when a fish of approximately $11 \mathrm{lbs}$ (5 kg) was captured (A. Clark pers. comm.). Based on current knowledge of the growth rates of the blue-finned phenotype and the demographic structure of the population by 1998 (see Pinder et al. in press), it seems highly probable that the bluefinned phenotype originated from the TEC hatchery and was introduced during the late 1980s. Understanding the ecological mechanisms responsible for the high population expansion of the blue-finned phenotype at the expense of the hump-backed phenotype in recent years is currently constrained by insufficient knowledge pertaining to the autecology and genetics of both phenotypes. However, life history traits, such as growth, age at maturity and fecundity are considered to be likely factors, with increased plasticity in the successful utilisation of key-function habitats (e.g. spawning, feeding) potentially providing the blue-finned mahseer with greater niche capacity to exploit and thus facilitating competitive displacement. In addition, direct predation and hybridisation have also been frequently cited as factors increasing the threat to endemic fishes through the introduction of new species (Crivelli 1995).

Since the Galibore fishery was closed in 2012, the fish community has been reported to have been subjected to elevated poaching pressure, but there are currently no means of measuring and tracking community and population metrics against the baseline data established from the current dataset. Accordingly, there is an immediate urgency to establish the status of the hump-backed mahseer throughout the Cauvery basin and acquire genetic material to secure the true taxonomic identity of this animal as a precursor to exploring potential species survival planning. 
Acknowledgements. We thank Sportquest Holidays Ltd, D. Plummer and M. Brown for the provision of catch records. We are grateful to A. Clarke and M. Clarke of the Trans World Fishing Team for historical insight into the fishery and A. Kanagavel for assisting in the production of Fig. 1. This research was supported by the Mahseer Trust.

\section{LITERATURE CITED}

Carrizo SF, Smith KG, Darwall WRT (2013) Progress towards a global assessment of the status of freshwater fishes (Pisces) for the IUCN Red List: application to conservation programmes in zoos and aquariums. Int Zoo Yearb 47:46-64

Collen B, Whitton F, Dyer EE, Baillie JEM and others (2014) Global patterns of freshwater species diversity, threat and endemism. Glob Ecol Biogeogr 23:40-51

Cooke SJ, Paukert C, Hogan Z (2012) Endangered river fish: factors hindering conservation and restoration. Endang Species Res 17:179-191

Crivelli AJ (1995) Are fish introductions a threat to endemic freshwater fishes in the northern Mediterranean region? Biol Conserv 72:311-319

Dahanukar N, Raghavan R, Ali A, Abraham R, Shaji CP (2011) The status and distribution of freshwater fishes of the Western Ghats. In: Molur S, Smith KG, Daniel BA, Darwall WRT (comps.) The status and distribution of freshwater biodiversity in the Western Ghats, India. IUCN Cambridge and Zoo Outreach Organization, Coimbatore, p 21-48

Dandekar P (2011) India's community fish sanctuaries protect wild fish and rivers. World River Rev 26:1-7

Desai VR (2003) Synopsis of biological data on the tor mahseer Tor tor (Hamilton, 1822). FAO Fisheries Synopsis No. 158. FAO, Rome

Dhu S (1923) The angler in India or the mighty mahseer. Natraj Publishers, Dehra Dun

> Dudgeon D (2011) Asian river fishes in the Anthropocene: threats and conservation challenges in an era of rapid environmental change. J Fish Biol 79:1487-1524

Everard M, Kataria G (2011) Recreational angling markets to advance the conservation of a reach of the Western Ramganga River, India. Aquat Conserv 21:101-108

Giam X, Ng TH, Lok AF, Ng HH (2011) Local geographic range predicts freshwater fish extinctions in Singapore. J Appl Ecol 48:356-363

Helfman G (2007) Fish conservation. Island Press, Washington, DC

Hora SL (1943) The game fishes of India. XVI. The mahseers or the large-scaled barbels of India. 9. Further observations on mahseers from the Deccan. J Bombay Nat Hist Soc $44: 1-8$

Jayaram KC (1997) Nomenclatural and systematic status of Barbus mussullah Sykes, 1839. J Bombay Nat Hist Soc 94:48-55

Khare P, Mohindra V, Barman AS, Singh RK, Lal KK (2014) Molecular evidence to reconcile taxonomic instability in mahseer species (Pisces: Cyprinidae) of India. Org Divers Evol 14:307-326

Editorial responsibility: Uwe Krumme, Rostock, Germany
Knight JDM, Rai A, D'souza RKP (2013) On the identities of Barbus mussullah Sykes and Cyprinus curmuca Hamilton, with notes on the status of Gobio canarensis Jerdon (Teleostei: Cyprinidae). Zootaxa 3750:201-215

MacDonald ASJ (1948) Circumventing the Mahseer. Natraj Publishers, Dehra Dun

> McClenachan L (2009) Documenting loss of large trophy fish from the Florida Keys with historical photographs. Conserv Biol 23:636-643

> McClenachan L, Ferretti F, Baum JK (2012) From archives to conservation: why historical data are needed to set baselines for marine animals and ecosystems. Conserv Lett 5:349-359

Millennium Ecosystem Assessment (2005) Ecosystems and human well-being: wetlands and water synthesis. World Resources Institute, Washington, DC

> Nautiyal P (2014) Review of the art and science of Indian mahseer (game fish) from nineteenth to twentieth century: road to extinction or conservation? Proc Natl Acad Sci India Sect B (Biol Sci) 84:215-236

Ogale SN (2002) Mahseer breeding and conservation and possibilities of commercial culture. The Indian experience. In: Petr T, Swar DB (Eds) Cold water fisheries in the Trans Himalayan countries. FAO Fish Tech Pap 431. FAO, Rome, p 193-212

Ogale SN, Kulkarni CV (1987) Breeding of pond-raised hybrids of mahseer fish, Tor khudree (Sykes) and Tor tor (Ham.). J Bombay Nat Hist Soc 84:332-335

Pinder AC, Raghavan R (2013) Conserving the endangered mahseers (Tor spp.) of India: the positive role of recreational fisheries. Curr Sci 104:1472-1475

Pinder AC, Raghavan R, Britton JR (in press) Efficacy of angler catch data as a population and conservation monitoring tool for the flagship mahseer fishes (Tor spp.) of Southern India. Aquat Conserv, doi:10.1002/ aqc. 2543

> Raghavan R, Ali A, Dahanukar N, Rosser A (2011) Is the Deccan Mahseer, Tor khudree (Sykes, 1839) (Pisces: Cyprinidae) fishery in the Western Ghats Hotspot sustainable? A participatory approach to stock assessment. Fish Res 110:29-38

Raghavan R, Dahanukar N, Tlusty MF, Rhyne AL, Krishna Kumar K, Molur S, Rosser AM (2013) Uncovering an obscure trade: threatened freshwater fishes and the aquarium pet markets. Biol Conserv 164:158-169

> Raghavan R, Dahanukar N, Philip S, Iyer P, Kumar B, Daniel BA, Molur S (2015) Conservation status of freshwater decapod crustaceans in the Western Ghats of India: an exceptional region of freshwater biodiversity. Aquat Conserv Mar Freshw Ecosyst 25:259-275

Sehgal K (1999) Coldwater fish and fisheries in the Western Ghats, India. In: Petr T (ed) Fish and fisheries at higher altitudes: Asia. FAO Fish Tech Pap 385. FAO, Rome, p 103

Shanmukha SN (1996) Status of mahseer fishery in Karnataka. Fish Chimes 15:26-29

Thomas HS (1873) The rod in India. C. Stolz, Mangalore

TWFT (Trans World Fishing Team) (1984) Quest for a legendary fish. International Book Distributors, Dehra Dun

Submitted: October 13, 2014; Accepted: February 21, 2015

Proofs received from author(s): May 5, 2015 